\title{
Politamide, a new constituent from the stem bark of Ficus polita Vahl (Moraceae)
}

\author{
Justin Kamga, ${ }^{\text {a }}$ Louis P. Sandjo, ${ }^{\text {a,b, } *}$ Hervé M. Poumale, ${ }^{\text {a,c }}$ Bathélémy Ngameni, ${ }^{\text {d }}$ Yoshihito \\ Shiono, ${ }^{\mathrm{c}}$ Mehdi Yemloul, ${ }^{\mathrm{e}}$ Vincent Rincheval, ${ }^{\mathrm{f}}$ Bonaventure T. Ngadjui, ${ }^{\mathrm{a}, \mathrm{d}, *}$ and Gilbert \\ Kirsch $^{\mathbf{b}}$ \\ ${ }^{a}$ Department of Organic Chemistry of the University of Yaoundé I, P.O. Box 812 Yaoundé \\ Cameroon \\ ${ }^{b}$ Laboratoire d'Ingénierie Moléculaire et Biochimie Pharmacologique, Institut Jean Barriol, \\ University of Paul-Verlaine Metz, 1Bld Arago 57070 Metz, France \\ ${ }^{c}$ Department of Bioresource Engineering, Faculty of Agriculture, Yamagata University, \\ Tsuruoka, Yamagata 997-8555, Japan \\ ${ }^{d}$ Department of Pharmacy and traditional Pharmacopeia of the Faculty of Medicine and \\ Biomedical Sciences P.O. Box. 8664 Yaoundé, Cameroon \\ ${ }^{e}$ Laboratoire de Méthodologie RMN, Institut Jean Barriol, University Henri Poincaré, Faculty \\ of Science, P.O. Box 239- 54506, Vandoeuvre-les-Nancy Cedex, France \\ ${ }^{f}$ Laboratoire de Génétique et Biologie Cellulaire, University of Versailles-St-Quentin-en- \\ Yvelines, Bâtiment Fermat - Maison 4; Niveau 2; 45, avenue des Etats-Unis, 78035 Versailles \\ Cedex, France \\ E-mail:plsandjo@yahoo.fr,ngadjuibt@yahoo.fr
}

\begin{abstract}
A new cerebroside 1 characterized as (2R,9Z)-2-hydroxy- $N-\{(1 S, 2 S, 3 R, 4 S)-1-[(\beta-\mathrm{D}$ glucopyranosyloxy)methyl]-2,3,4-trihydroxyoctacosan-1-yl\}-9-pentadecenamide was isolated from the stem bark of Ficus polita Vahl (Moraceae) together with four known compounds identified as sitosterol 3-O- $\beta$-D-glucopyranoside 2, betulinic acid 3, stigmasterol 4 and lupeol 5 . Their structures were determined on the basis of spectroscopic methods as well as HR-ESI-MS, NMR analyses, chemical transformation, and by comparison of their physical and spectral data with those reported in the literature and with authentic specimens for some known compounds.
\end{abstract}

Keywords: Ficus polita, moraceae, cerebroside 


\section{Introduction}

The plants are always a great source of drugs discovery. It is the case of Ficus which is a genus endemic in west, central, north and east Africa. ${ }^{1,2}$ The leaves of some species are used in Ivory Coast folk medicine to treat worms and abdominal pains. ${ }^{3}$ Some previous biological studies have shown that some species have anti-HIV ${ }^{4}$ and antimicrobial properties. ${ }^{5}$ That is why our attention is focused on Ficus polita (Moraceae) which is a small tree about 10 to 15 meters high. ${ }^{1}$ The discovery of bioactive compounds prompted us to investigate this plant. This paper deals with isolation, structural elucidation of a new cerebroside based on the spectrometric methods.

\section{Results and Discussion}

The methanolic crude extract was subjected to repeated columns chromatography yielding a new cerebroside 1, 3-O- $\beta$-D-glucopyranoside sitosterol $2,{ }^{6}$ betulinic acid $3,{ }^{7}$ stigmasterol $4^{8}$ and lupeol $5 .{ }^{9}$

Compound 1 was obtained as a dark amorphous solid from mixture $\mathrm{CH}_{2} \mathrm{Cl}_{2} / \mathrm{MeOH}$ (9:1). The positive test with Molisch reagent suggested that, $\mathbf{1}$ is a glycosylated compound. Its positive mode HRESI-MS spectrum showed a peak at $\mathrm{m} / \mathrm{z} 910.6869$ (calcd 910.6954) corresponding to the formula $\left[\mathrm{C}_{50} \mathrm{H}_{97} \mathrm{O}_{11} \mathrm{~N}+\mathrm{Na}\right]^{+}$requiring 3 double bond equivalents. The FT-IR spectrum exhibited a broad absorption band for $\mathrm{OH}$ groups $\left(3368 \mathrm{~cm}^{-1}\right)$, two strong absorption bands for olefinic functions $\left(1649 \mathrm{~cm}^{-1}\right)$ and for secondary amide $\left(1637\right.$ and $\left.1542 \mathrm{~cm}^{-1}\right){ }^{10}$ The NMR spectra of 1 displayed signals corresponding to those of a phytoceramide. ${ }^{11}$ In fact, a triplet of $6 \mathrm{H}$ was observed at $\delta_{\mathrm{H}} / \delta_{\mathrm{C}} 0.83(J=5.9 \mathrm{~Hz}) / 13.9$ and assigned to the two terminal $\mathrm{CH}_{3}$ groups. A broad singlet observed between $\delta_{\mathrm{H}} / \delta_{\mathrm{C}} 1.22-1.75 /(24.2-29.0)$ corresponded to the sequence of $\mathrm{CH}_{2}$ groups. A proton signal linked to a nitrogen $(\underline{\mathbf{H}}-\mathrm{N})$ appeared as doublet at $\delta_{\mathrm{H}} 7.50(J=9.2 \mathrm{~Hz})$ and the other linked to azomethine at $\delta_{\mathrm{H}} / \delta_{\mathrm{C}} 4.11(\mathrm{brd}, J=8.8 \mathrm{~Hz}) / 49.8$. Furthermore this information, a set of signals of $\beta$-D-glucopyranose was observed on both spectra which showed an anomeric proton at $\delta_{\mathrm{H}} / \delta_{\mathrm{C}} 4.12(\mathrm{~d}, J=8.0 \mathrm{~Hz}) / 103.4$, four oxymethines at $\delta_{\mathrm{H}} / \delta_{\mathrm{C}} 3.35(\mathrm{~m}) / 73.4$, $3.05(\mathrm{~m}) / 76.4,3.10(\mathrm{~m}) / 70.0,3.16(\mathrm{~m}) / 76.8$ and the oxymethylene at $\delta_{\mathrm{H}} / \delta_{\mathrm{C}}[3.65(\mathrm{dd}, J=3.0$, $11.8 \mathrm{~Hz}), 3.42(\mathrm{dd}, J=5.8,11.8 \mathrm{~Hz})] / 61.0^{12}$ In addition, the chemical shifts of a double bond having cis configuration ${ }^{11}$ were also observed at $\delta_{\mathrm{H}} 5.30(\mathrm{brd}, J=6.2 \mathrm{~Hz}) / 129.4$ and 5.33 (brd, $J$ $=6.2 \mathrm{~Hz}) / 130.1$. The foregoing data suggested to a glucophytoceramide derivative with an olefinic bond. The sugar moiety was located using long range correlations exhibited by the HMBC spectrum. This showed correlations from diastereotopic protons $\mathrm{H}-1 \mathrm{a}[3.65$ (dd, $J=5.8$, $10.6 \mathrm{~Hz})] / 69.5$ and $\mathrm{H}-1 \mathrm{~b}[3.90(\mathrm{~m})] / 69.5$ to the anomeric carbon at $\delta_{\mathrm{C}} 103.4$. Additional correlations were observed between the proton $\underline{\mathrm{H}}-\mathrm{N}$ at $\delta_{\mathrm{H}} 7.50$ and the carbonyl at $\delta_{\mathrm{C}} 173.6$ as well as other interactions from proton $\mathrm{H}-2$ ' at $\delta_{\mathrm{H}} / \delta_{\mathrm{C}} 3.85(\mathrm{~m}) / 70.8$ to carbonyl function (173.6) and both successive $\mathrm{CH}_{2}$ groups [C-3' $\left(\delta_{\mathrm{C}} 34.3\right)$, C-4' $\left(\delta_{\mathrm{C}} 24.2\right)$ ]. Fatty acid moiety is $\alpha-$ hydroxylated since the protons of $\alpha-\mathrm{OH}$ group $\left[\delta_{\mathrm{H}} 5.59(\mathrm{~d}, J=6.2 \mathrm{~Hz})\right]$ and the one of the oxymethine C-2' $\left[\delta_{\mathrm{H}} 3.85(\mathrm{~m}) / 70.8\right]$ correlated with the carbonyl (173.6). 
The spatial location of hydroxyl groups in sphingosine was evident by exploitation of NOESY spectrum (Scheme 1) which showed interactions between the proton at $\delta_{\mathrm{H}} 4.11$ and those at $\delta_{\mathrm{H}} 3.90,3.35$; both protons at $\delta_{\mathrm{H}} 3.35$ and 2.92 interacted with the one at $\delta_{\mathrm{H}} 4.90$ (브-C3 ) supporting that all the five protons were in the same spatial orientation.

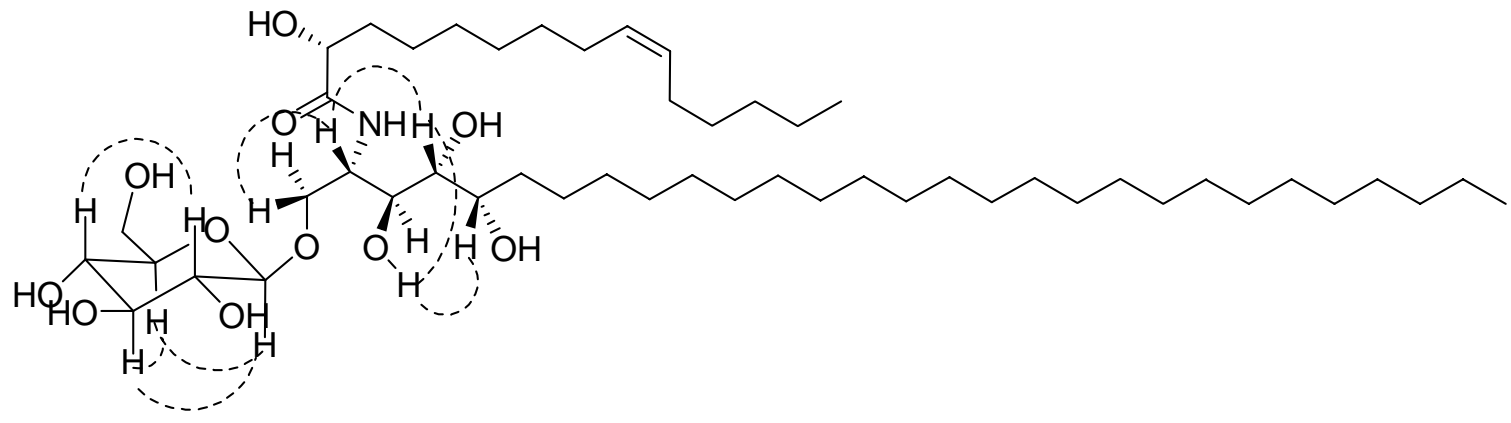

Scheme 1. Spatial interactions (NOESY) of compound $\mathbf{1 .}$

The absolute configurations of carbons C-2, C-3, C-4, and C-2' were determined to be $(S)$, $(S),(R)$ and $(R)$ respectively since the NMR data were close to those of phytoceramide. ${ }^{11}$ So the carbon C-5 is in the $(S)$ configuration considering its spatial position.

Table 1. The ${ }^{1} \mathrm{H}-\mathrm{NMR}$ (DMSO- $d_{6}, 400 \mathrm{MHz}$ ) and ${ }^{13} \mathrm{C}-\mathrm{NMR}(100 \mathrm{MHz}$ ) spectral data of compound 1

\begin{tabular}{|c|c|c|c|c|}
\hline Position & $\delta \mathrm{H}(\mathrm{J} \mathrm{Hz})$ & $\delta \mathrm{C}(\mathrm{APT})$ & Cosy & HMBC \\
\hline \multicolumn{5}{|l|}{ ceramide } \\
\hline $\mathrm{NH}$ & $7.50(\mathrm{~d}, 9.2)$ & - & 4.12 & $49.8,173.6$ \\
\hline \multirow[t]{2}{*}{1} & $3.65(\mathrm{dd}, 5.8,10.6, \mathrm{Ha})$ & 69.5 & $4.12,4.11$ & $49.8,103.4$ \\
\hline & $3.90(\mathrm{~m}, \mathrm{Hb})$ & & & \\
\hline 2 & $4.11(\mathrm{brd}, 8.8)$ & 49.8 & $3.90,7.50$ & 69.5 \\
\hline 3 & $3.10(\mathrm{dd}, 8.8,11.2)$ & 76.8 & 4.90 & $49.8,69.5$ \\
\hline 4 & $3.35(\mathrm{~m})$ & 69.9 & 4.75 & \\
\hline 5 & $2.92(\mathrm{dt}, 5.9,8.8,11.2)$ & 73.4 & $3.35,3.10$ & $69.9,76.8$ \\
\hline 6 & $1.95(\mathrm{~m}, \mathrm{Ha}), 2.10(\mathrm{~m}, \mathrm{Hb})$ & 31.9 & $1.22-1.75,3.35$ & 24.2-29.0, \\
\hline & & & & 73.4 \\
\hline 7-25, 4'-7', 12'-14' & $1.22-1.75$ (brs) & $24.2-29.0$ & $0.83,1.90,2.10$ & 13.9 \\
\hline 29,15 & $0.83(\mathrm{t}, 6.0, \mathrm{CH} 3)$ & 13.9 & $1.22-1.75$ & $24.2-29.0$ \\
\hline $1^{\prime}(\mathrm{C}=\mathrm{O})$ & - & 173.6 & - & - \\
\hline 2 ' & $3.85(\mathrm{~m})$ & 70.9 & $1.90,5.59$ & $\begin{array}{l}24.2,34.1, \\
173.6\end{array}$ \\
\hline 3 ' & $1.61(\mathrm{~m}, \mathrm{Ha}), 1.90(\mathrm{~m}, \mathrm{Hb})$ & 34.1 & $1.22,2.10$ & $24.2,70.9$ \\
\hline 9' & $5.30(\mathrm{brd}, 6.2)$ & 129.4 & $2.00,5.33$ & $26.7,130.1$ \\
\hline
\end{tabular}


Table 1. Continued

\begin{tabular}{|c|c|c|c|c|}
\hline Position & $\delta \mathrm{H}(\mathrm{J} \mathrm{Hz})$ & $\delta \mathrm{C}(\mathrm{APT})$ & Cosy & HMBC \\
\hline $10^{\prime}$ & 5.33 (brd, 6.2) & 130.1 & $1.90,5.30$ & 129.4 \\
\hline $8^{\prime}, 11^{\prime}$ & $1.90(\mathrm{~m}, \mathrm{Ha}), 2.00(\mathrm{~m}, \mathrm{Hb})$ & 26.7 & $5.30,5.33$ & $129.4,130.1$ \\
\hline $\mathrm{OH}(\mathrm{C} 3)$ & $4.90(\mathrm{~d}, 6.2)$ & - & 3.10 & $69.5,76.8$ \\
\hline $\mathrm{OH}(\mathrm{C} 4)$ & $4.75(\mathrm{~d}, 6.2)$ & - & 3.35 & $49.8,73.4$ \\
\hline $\mathrm{OH}\left(\mathrm{C} 2{ }^{\prime}\right)$ & $5.59(\mathrm{~d}, 6.2)$ & - & 3.85 & $\begin{array}{l}34.1,70.9, \\
173.6\end{array}$ \\
\hline \multicolumn{5}{|l|}{ Glucose } \\
\hline $1 "$ & $4.12(\mathrm{~d}, 8.0)$ & 103.4 & & 69.5 \\
\hline $2 "$ & $3.35(\mathrm{~m})$ & 73.4 & 4.95 & 103.4 \\
\hline $3 "$ & $3.05(\mathrm{~m})$ & 76.4 & & \\
\hline $4 "$ & $3.10(\mathrm{~m})$ & 70.0 & 4.90 & \\
\hline $5 "$ & $3.16(\mathrm{~m})$ & 76.8 & & \\
\hline \multirow[t]{2}{*}{$6 "$} & $3.42(\mathrm{dd}, 5.8,11.8)$ & 61.0 & 4.55 & 76.8 \\
\hline & $3.65(\mathrm{dd}, 3.0,11.8)$ & & & \\
\hline $\mathrm{OH}(\mathrm{C} 2 ’ ’)$ & $5.01(\mathrm{brd}, 6.2)$ & - & $3.35,3.05$ & $\begin{array}{l}73.4,76.4 \\
103.4\end{array}$ \\
\hline $\mathrm{OH}\left(\mathrm{C} 4{ }^{\prime \prime}\right)$ & $4.90(\mathrm{brd}, 6.2)$ & - & 3.10 & $\begin{array}{l}70.0,76.4 \\
76.8\end{array}$ \\
\hline $\mathrm{OH}(\mathrm{C} 6$ '”) & $4.55(\mathrm{dd}, 3.0,6.2)$ & - & $3.42,3.65$ & $61.0,76.8$ \\
\hline
\end{tabular}

Methanolysis $\left(0.9 \mathrm{~N} \mathrm{HCl} / \mathrm{MeOH}\right.$, at $70{ }^{\circ} \mathrm{C}$ during $\left.18 \mathrm{~h}\right)$ of compound 1 gave the fatty acid methyl ester and the long chain base which were characterized by LC-ESI-MS analysis. The peak at $\mathrm{m} / \mathrm{z} 270$ (Retention time: $8.87 \mathrm{~min}$ ) corresponded to a fatty acid methyl ester having two double bond equivalents (carbonyl function and $\mathrm{C}=\mathrm{C}$ double bond). The position of olefin function was determined by fragment ions obtained on the FAB-MS spectrum (Scheme 2). 


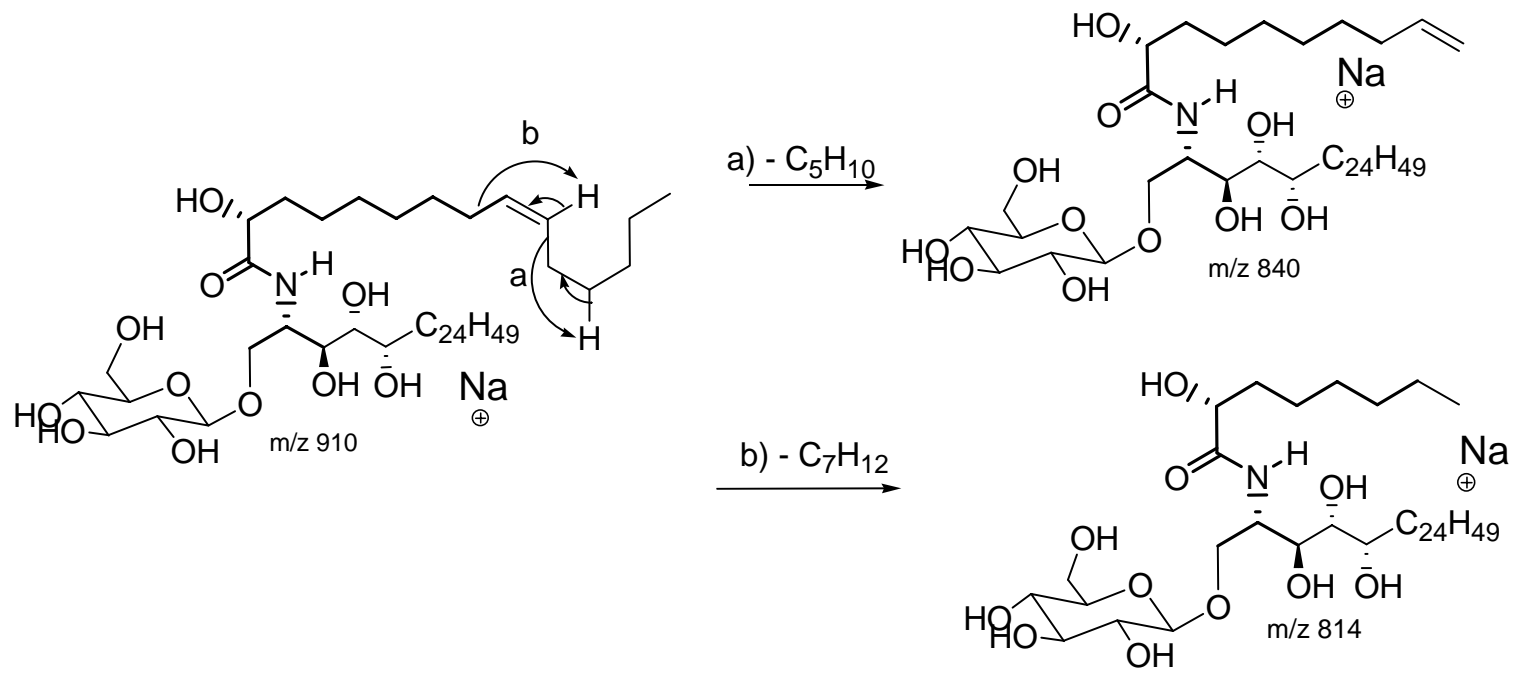

Scheme 2. Proposal of fragmentation mechanism justifying olefin bond position in fatty acid side.

From information above-mentioned, 1 was identified as (2R,9Z)-2-hydroxy- $N$ $\{(1 S, 2 S, 3 R, 4 S)-1-[(\beta-D$-glucopyranosyloxy)methyl]-2,3,4-trihydroxyoctacosan-1-yl $\}-9$ pentadecenamide.

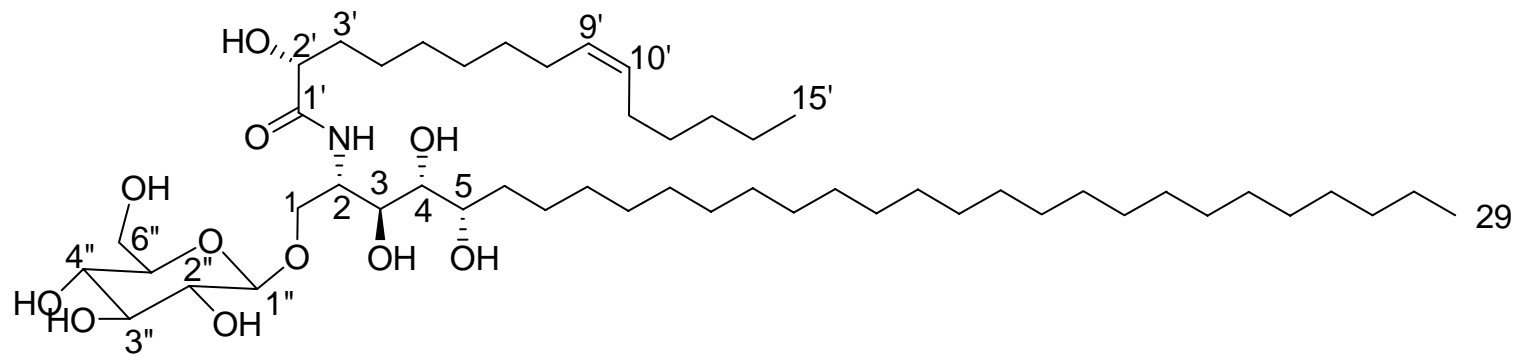

1

\section{Experimental Section}

General. Vacuum column chromatography (VCC), column chromatography (CC) and thin layer chromatography (TLC) were performed over silica gel $60 \mathrm{H}$ (particle size $90 \%<45 \mathrm{~mm}$ ), or 200 - 300 mesh silica gel silica gel GF254, respectively. Melting points (m.p.): Stuart Scientific Melting Point apparatus SMP3; uncorrected. Optical rotations: Perkin Elmer polarimeter model 341 at $589 \mathrm{~nm}$. IR Spectra: Perkin-Elmer FT-IR system spectrum BX spectrometer, KBr disks. HR-ESI-MS and FAB-MS were recorded by micro-TOF-Q 98 (Bruker-Daltonics, Germany) and JEOL JMS-700 (Japan) instruments respectively. ${ }^{1} \mathrm{H}$ - and ${ }^{13} \mathrm{C}-\mathrm{NMR}$ : Bruker DRX-400 MHz for 1 D- and 2D-NMR spectrum. LC-MS analyses were performed on an HPLC system (LC pump P4000 and autosampler AS3000 from Thermo Separation Products) coupled to a LCQ Duo on 
Trap detector (Thermo Electron, Zellik, Belgium) equipped with an ESI interface run in the positive ion mode. The separation of sample components was achieved on an X-Terra MS C18 (5 $\mu \mathrm{m}$ particle size, $3.9 \times 150 \mathrm{~mm}$ ) (Waters, Overijse, Belgium), equipped with an X-Terra MS $\mathrm{C} 18$ pre-column $(5 \mu \mathrm{m}$ particle size, $3.9 \times 10 \mathrm{~mm})$ and operated at $37{ }^{\circ} \mathrm{C}$. Injection volume was $15 \mu \mathrm{L}$. The mobile phase consisted of a mixture of $5 \mathrm{mM}$ ammonium formate buffer at $\mathrm{pH} 3.8$ (A) and acetonitrile (B). Separation conditions for all compounds were as follows: 0.0-0.50 min, $\mathrm{A} / \mathrm{B}$ hold at 50/50, v/v; 0.50-9.0 min, eluant B increase to 97\%; 9.0-12.0 min, eluant B hold at $97 \%, 12.0-12.5 \mathrm{~min}$, eluant decrease to $50 \%, 12.5-13.0 \mathrm{~min}, \mathrm{~A} / \mathrm{B}$ hold at 50/50, Before each run the column was equilibrated for $6 \mathrm{~min}$ at A/B 50/50. The flow rate for column equilibration and analytical runs was $0.4 \mathrm{ml} / \mathrm{min}$. Ionization of the analytes was carried out as follows: sheath gas flow rate (nitrogen), 47 arbitrary units; auxiliary gas flow rate (helium), 18 arbitrary units; spray voltage, $5.0 \mathrm{kV}$; capillary temperature, $200{ }^{\circ} \mathrm{C}$; capillary voltage, $36 \mathrm{~V}$; Data acquisition was performed in a time segment between 0.2 and $11.5 \mathrm{~min}$ after injection. The full MS-MS spectrum of $[M+\mathrm{H}]^{+}$ions was monitored for all compounds, isolation width was $2.5 \mathrm{~m} / \mathrm{z}$, normalized collision energy was $28.0 \%$.

\section{Extraction and isolation}

Ficus polita (Moraceae) was collected From Yaoundé central region of Cameroon in May 2007. A sample $\left(\mathrm{N}^{\circ} 39955 / \mathrm{HNC}\right)$ has been deposited in the National Herbarium of Yaoundé, Cameroon.

Dried stem bark of $F$. polita $(3.4 \mathrm{~kg})$ was cut into small pieces, powdered and extracted 2 times by maceration with $10 \mathrm{~L}$ of mixture $\mathrm{CH}_{2} \mathrm{Cl}_{2} / \mathrm{MeOH}$ (1:4) during $72 \mathrm{~h}$ (each time lasted 72 hours). Organic extract was concentrated to yield $204 \mathrm{~g}$ of crude extract which were subjected to the VCC $\left(\mathrm{SiO}_{2}\right.$, hexane, hexane/ EtOAc 3:1 to 1:1, EtOAc in order of increasing polarity and $\mathrm{MeOH}$ ) yielding 5 fractions $\mathrm{A}-\mathrm{E}$. A was purified by $\mathrm{CC}$ with different mixtures of hexane/EtOAc yielding 157 fractions. The ones (36-40) eluted in the ratio 9:1 yielded lupeol $(29.5 \mathrm{mg})$. From the fraction B, 90 fractions were obtained and stigmasterol $(240 \mathrm{mg})$ was isolated from the fractions $30-40$ eluted in the ratio 17:3. From the same fraction $\mathrm{B}, 5 \mathrm{mg}$ of betulinic acid were isolated from the fractions 42-44 eluted with the mixture Hexane/EtOAc (4:1). EtOAc fraction (D) was further eluted with a mixture of $\mathrm{CH}_{2} \mathrm{Cl}_{2} / \mathrm{MeOH}$ with increasing polarity. 104 fractions was obtained and from the ones 20-36 eluted with the mixture $\mathrm{CH}_{2} \mathrm{Cl}_{2} / \mathrm{MeOH}$ (19:1), the 3-O- $\beta$-D-glucopyranoside of $\beta$-sitosterol (11.0 mg) was isolated. From the same fraction $\mathrm{D}$, politamide $(15 \mathrm{mg})$ was obtained from the fractions $94-104$ eluted in the ration 9:1.

Politamide (1). Dark amorphous solid; M.p 168.5-170.5; [ $\alpha{ }_{\mathrm{D}^{+}}^{20} 0.009$ (c 0.075, DMSO). FT-IR: 3368, 1649, 1637, 1542, and 1468. ${ }^{1} \mathrm{H}-$ and ${ }^{13} \mathrm{C}-\mathrm{NMR}:$ Table 1. HR-ESI-MS: 910.6869 $\left[\mathrm{C}_{50} \mathrm{H}_{97} \mathrm{O}_{11} \mathrm{~N}+\mathrm{Na}\right]^{+}, 926.6825\left[\mathrm{C}_{50} \mathrm{H}_{97} \mathrm{O}_{11} \mathrm{~N}+\mathrm{K}\right]^{+}, 896.6749\left[\mathrm{C}_{50} \mathrm{H}_{97} \mathrm{O}_{11} \mathrm{~N}-\mathrm{CH}_{2}+\mathrm{Na}\right]^{+}, 882.6594$ $\left[\mathrm{C}_{50} \mathrm{H}_{97} \mathrm{O}_{11} \mathrm{~N}-\mathrm{C}_{2} \mathrm{H}_{4}+\mathrm{Na}\right]^{+}, 770.5387\left[\mathrm{C}_{50} \mathrm{H}_{97} \mathrm{O}_{11} \mathrm{~N}-\mathrm{C}_{10} \mathrm{H}_{20}+\mathrm{Na}\right]^{+}$; ESI-MS-MS of the peak at m/z 910: $684\left[\mathrm{C}_{50} \mathrm{H}_{97} \mathrm{O}_{11} \mathrm{~N} \text {-glucose- } \mathrm{H}_{2} \mathrm{O}-\mathrm{C}_{2} \mathrm{H}_{4}+\mathrm{Na}\right]^{+}, 668\left[\mathrm{C}_{50} \mathrm{H}_{97} \mathrm{O}_{11} \mathrm{~N}-\mathrm{CH}_{3} \mathrm{OH}-\mathrm{C}_{15} \mathrm{H}_{30}+\mathrm{Na}\right]^{+}, 624$ $\left[\mathrm{C}_{50} \mathrm{H}_{97} \mathrm{O}_{11} \mathrm{~N}-\mathrm{CH}_{3} \mathrm{OH}-\mathrm{C}_{18} \mathrm{H}_{36}+\mathrm{Na}\right]^{+}$; FAB-MS $814\left[\mathrm{M}-\mathrm{C}_{7} \mathrm{H}_{12}+\mathrm{Na}\right]^{+}, 840\left[\mathrm{M}-\mathrm{C}_{5} \mathrm{H}_{10}+\mathrm{Na}\right]^{+}$. 
Methanolysis and LC-ESI-MS analysis. Compound $1(1.2 \mathrm{mg})$ was refluxed $\left(70{ }^{\circ} \mathrm{C}\right)$ for $18 \mathrm{~h}$ in $2.5 \mathrm{~mL}$ of $\mathrm{MeOH}$ containing $1.5 \mathrm{~mL}$ of $0.9 \mathrm{~N} \mathrm{HCl}$ under magnetic stirring. The mixture was neutralized with aqueous solution of $\mathrm{Na}_{2} \mathrm{CO}_{3}$ and extracted with $\mathrm{CHCl}_{3}$. The fatty acid methyl ester was carefully characterized by LC-ESI-MS at $\mathrm{m} / z 270$ (Retention time: $8.87 \mathrm{~min}$ ).

\section{Acknowledgements}

L. P. Sandjo would like to thank EGIDE and SCAC (Service de Cooperation et d'Actions Culturelles: French Grant Government No. 607832K) for their financial support and Health National Laboratory, Toxicological Division, University of Luxembourg. Dr. H.M. Poumale is thankful to the JSPS (Japan Society for the Promotion of Science) for the Postdoctoral fellowship through financial support (P08430) and a research stay at the University of Yamagata.

\section{References}

1. Berhaut, J.; Flore illustrée du Sénégal, Dakar; 1979, Vol. VI, p 471.

2. Abdel-Hameed, E-S. S. Food Chemistry 2009, 114, 1271.

3. Diehl, M. S.; Atindehou, K. K.; Téré, H.; Betschart, B. J. Ethnopharmacol. 2004, 95, 277.

4. Ayissi, N K.; Nyadedzor, C. Antiviral Research 2003, 58, 25.

5. Kuete, V.; Ngameni, B.; Simo, C. C. F.; Tankeu, R. K.; Ngadjui, B. T.; Meyer, J. J. M.; Lall, N.; Kuiate, J. R. J. Ethnopharmacol. 2008, 120, 17.

6. Walter, E. D. J. Pharm. Sci. 1963, 52, 708.

7. Siddiqui, S.; Hafeez, F.; Begum, S.; Siddiqui, B. S. J. Nat. Prod. 1988, 51, 229.

8. De-Eknamkul, W.; Potduang, B. Phytochemistry 2003, 62, 389.

9. Reynolds, W. F.; McLean, S.; Poplawski, J.; Enriquez, R. G.; Escobar, L. I.; Leon, I. Tetrahedron 1986, 42, 3419.

10. Kim, S. Y.; Choi, Y.-H.; Huh, H.; Kim, J.; Kim, Y. C.; Lee, H. S. J. Nat. Prod. 1997, 60, 274.

11. Sandjo, L. P.; Hannewald, P.; Yemloul, M.; Kirsch, G.; Ngadjui, B. T. Helv. Chim. Acta 2008, 91, 1326.

12. Chen, Y.-L.; Tan, C.-H.; Tan, J.-J.; Qu, S.-J.; Wang, H.-B.; Qiang, Z.; Jiang, S.-H.; Zhang, D.-Y. Helv. Chim. Acta 2007, 90, 2421. 